\title{
Inhibition of Resistance Gene-Mediated Defense in Rice by Xanthomonas oryzae pv. oryzicola
}

\author{
Seiko Makino, ${ }^{1}$ Akiko Sugio, ${ }^{2}$ Frank White, ${ }^{2}$ and Adam J. Bogdanove ${ }^{1}$ \\ ${ }^{1}$ Department of Plant Pathology, lowa State University, Ames, IA 50014, U.S.A.; ${ }^{2}$ Department of Plant Pathology, \\ Kansas State University, Manhattan, KS 66506, U.S.A.
}

Submitted 28 June 2005. Accepted 3 November 2005.

\begin{abstract}
Xanthomonas oryzae pv. oryzae and the closely related $X$. oryzae pv. oryzicola cause bacterial blight and bacterial leaf streak of rice, respectively. Although many rice resistance $(R)$ genes and some corresponding avirulence $(a v r)$ genes have been characterized for bacterial blight, no endogenous $a v r / R$ gene interactions have been identified for leaf streak. Genes avrXa7 and avrXa10 from X. oryzae pv. oryzae failed to elicit the plant defense-associated hypersensitive reaction (HR) and failed to prevent development of leaf streak in rice cultivars with the corresponding $R$ genes after introduction into $X$. oryzae pv. oryzicola despite the ability of this pathovar to deliver an AvrXa10:Cya fusion protein into rice cells. Furthermore, coinoculation of $X$. oryzae pv. oryzicola inhibited the $H R$ of rice cultivar IRBB10 to $X$. oryzae pv. oryzae carrying avrXa10. Inhibition was quantitative and dependent on the type III secretion system of $X$. oryzae pv. oryzicola. The results suggest that one or more $X$. oryzae pv. oryzicola type III effectors interfere with $a v r / R$ gene-mediated recognition or signaling and subsequent defense response in the host. Inhibition of $R$ gene-mediated defense by $X$. oryzae pv. oryzicola may explain, in part, the apparent lack of major gene resistance to leaf streak.
\end{abstract}

Additional keywords: phytopathogenic bacteria.

The ability of plants to perceive and defend against pathogen attack is partially governed by the interaction between plant resistance $(R)$ genes and pathogen avirulence (avr) genes. These gene-for-gene interactions underlie cultivar and race specificity in the resistance of plants to pathogenic viruses, bacteria, and fungi (Flor 1971; Keen 1990). $R$ gene products directly or indirectly recognize corresponding $a v r$ gene products and trigger downstream signaling to activate defense responses (Martin et al. 2003). In the absence of either the $R$ gene or the $a v r$ gene, plants fail to mount sufficient defense responses and succumb to disease. The hypersensitive reaction (HR) is an early, $R$ gene-mediated response to avirulence signals. HR is localized host-cell death associated with limitation of pathogen spread in host-plant tissues (Hammond-Kosack and Jones 1996; Klement 1982; Wright and Beattie 2004).

In phytopathogenic bacteria, most known Avr signals are proteins delivered to plant cells via a specialized secretion pathway called the Hrp or type III secretion system (TTSS) (Bogdanove et al. 1996; Buttner and Bonas 2002; Cornelis and Van Gijsegem 2000). The TTSS is broadly conserved among gram-negative animal and plant pathogens as a specific path-

Corresponding author: Adam J. Bogdanove; E-mail: ajbog@iastate.edu way for delivery of virulence factors into host cells (Hueck 1998). Cya, an adenylate cyclase of Bordetella pertussis, activity of which depends on calmodulin produced in the host cell, has been used in translational fusions as a quantitative reporter for type III effector delivery in both animals and plants (CasperLindley et al. 2002; Sory and Cornelis 1994).

Many Avr proteins, in the absence of a corresponding R gene, contribute demonstrably to virulence (Bai et al. 2000; Swarup et al. 1991). The general term effector is used for all substrates of the TTSS delivered to host cells. The dual roles of some type III effectors is probably a consequence of the evolution in plants of the ability to recognize those effectors and mount resistance as mediated by $R$ genes (Alfano and Collmer 2004). Recently, the functions of some type III effectors have been elucidated and some have been shown to suppress plant defense responses, including both $R$ gene-mediated and nonhost $\mathrm{HR}$ as well as cell-wall fortification and other resistance mechanisms (Abramovitch and Martin 2004; Chang et al. 2004)

Bacterial blight, caused by Xanthomonas oryzae pv. oryzae, is one of the most important diseases of rice (Mew et al. 1993). The disease is characterized by a high degree of race and cultivar specificity, with over 30 races of $X$. oryzae pv. oryzae and more than 25 bacterial blight $R$ genes identified (Lee et al. 2003; Noda et al. 1996; Yang et al. 2003). Effectors found in a major class of $X$. oryzae pv. oryzae are members of the $a v r B s 3 / p t h A$ family (Bai et al. 2000; Bonas et al. 1989; Hopkins et al. 1992; Yang and White 2004; Yang et al. 2000, 2005; Zhu et al. 1998). Of these, avrXa7 and avrXa10 were cloned from the X. oryzae pv. oryzae PXO86 (race 2; Hopkins et al. 1992) and correspond to the $R$ genes $\mathrm{Xa} 7$ and $\mathrm{Xa10}$, respectively. In PXO86 and KXO85, avrXa7 contributes markedly to disease (Bai et al. 2000; Yang and White 2004). In strains lacking $a v r X a 7$, other members of the gene family act as major virulence factors (Yang and White 2004). The protein structures of this family share a highly conserved N-terminus, a central region of 34 aa, direct, near-perfect repeats, which vary in number, and a $\mathrm{C}$-terminal region containing functional nuclear localization signals (NLS) and an acidic transcription activation domain (AAD) (Buttner and Bonas 2002; Szurek et al. 2001; Zhu et al. 1998). Type III secretion and delivery of AvrBs3 is directed by sequences in the N-terminus (Szurek et al. 2002), which is nearly identical to and interchangeable with the N-termini of AvrXa7 and AvrXa10 (Hopkins et al. 1992; Yang and White 2004; Yang et al. 2000, 2005). The NLS are required for avirulence activity of some but not all members of the AvrBs3 family, indicating that different members are recognized differently (Ballvora et al. 2001). The AAD at the C-terminus suggests an interaction with plant transcriptional machinery during infection and determines R-protein specificity for some mem- 
bers (Yang and White 2004, 2005; Zhu et al. 1998, 1999). The repeat domains of AvrBs3 and AvrXa7 also contribute to their $R$-gene specificity (Herbers et al. 1992; Yang et al. 2005).

$X$. oryzae pv. oryzicola is closely related to $X$. oryzae $\mathrm{pv}$. oryzae, showing more than $90 \%$ similarity by DNA-DNA hybridization (Swings et al. 1990). Unlike X. oryzae pv. oryzae, which invades the xylem to infect systemically, $X$. oryzae pv. oryzicola is a nonvascular pathogen (Ou 1985). Leaf streak can also cause severe yield losses, though it occurs more sporadically than blight (Mew 1993). Like X. oryzae pv. oryzae, X. oryzae pv. oryzicola harbors multiple members of the avrBs3/pthA family (Yang and White 2004), but no function has yet been ascribed to them. Notably, despite some effort (Das 1977; Rao et al. 1972), no endogenous $a v r$ and $R$-gene combination has been identified for $X$. oryzae pv. oryzicola and rice. We therefore investigated whether $X$. oryzae pv. oryzicola has the capacity to express and deliver members of the AvrBs3/PthA family using avrXa7 and avrXal0 and rice cultivars containing $\mathrm{Xa} 7$ or $\mathrm{Xa10}$.

\section{RESULTS}

Expression of $X$. oryzae pv. oryzae avr genes in $X$. oryzae pv. oryzicola does not cause avirulence to rice cultivars with corresponding $R$ genes.

To determine whether $a v r$ genes of $X$. oryzae pv. oryzae function in $X$. oryzae pv. oryzicola, the plasmids pHMavrXa10 and pHMavrXa7 (Table 1), which carry avrXal0 and avrXa7, respectively, fused to the FLAG epitope tag (Brizzard et al. 1994), were transformed into $X$. oryzae pv. oryzicola strains BLS303 and BLS256 (Table 1). None of the resulting strains induced HR when infiltrated into leaves of corresponding rice cultivars IRBB10 and IRBB7, which carry resistance genes $\mathrm{Xa10}$ and $\mathrm{Xa7}$, respectively. Instead, transformants caused lesions that were water-soaked in appearance and typical of the parental strains (Fig. 1). Both plasmids conferred the ability to elicit HR in the respective cultivars when introduced into $X$. oryzae pv. oryzae PXO99 ${ }^{\mathrm{A}}$ (Fig. 1). Population growth of BLS303(pHMavrXa10) in IRBB10 was not significantly different from that of BLS303 (Fig. 1). Western blot analysis using anti-FLAG antibody confirmed expression of AvrXa10 in BLS303(pHMavrXa10) (data not shown). Thus, avrXa10, and most likely avrXa7, was expressed in $X$. oryzae pv. oryzicola but failed to render the pathogen avirulent.

\section{$X$. oryzae pv. oryzicola harboring avrBs3 elicits the HR of pepper in a $B$ s3-dependent manner.}

To determine if the apparent lack of avirulence function was specific for rice or due more generally to a failure in type III secretion, the ability of $X$. oryzae pv. oryzicola to deliver AvrBs3 and elicit a Bs3-dependent response in pepper was examined. pHMavrBs3, identical to pHMavrXa10 except for the coding region of the $a v r$ gene (Table 1), was transformed into $X$. oryzae pv. oryzicola strains BLS303 and BLS256 as well as $X$. oryzae pv. oryzae $\mathrm{PXO} 99^{\mathrm{A}}$, and the resulting strains were infiltrated into leaves of six-week old plants of pepper varieties ECW30R, which carries Bs3, and the near-isogenic line ECW, which lacks the resistance gene. The parental $X$. oryzae pv. oryzicola and $X$. oryzae pv. oryzae strains did not elicit an HR in ECW30R (Fig. 2, top panels). However, the transformants carrying pHMavrBs3 did elicit an HR (Fig. 2, bottom panels). None of the strains elicited an HR on ECW (data not shown). Thus, $X$. oryzae pv. oryzicola effectively expresses and translocates AvrBs3 into pepper, indicating that the inability of AvrXa7

Table 1. Bacterial strains and plasmids used in this study

\begin{tabular}{|c|c|c|}
\hline Strain or plasmid & Relevant characteristics $^{\mathrm{z}}$ & Source or reference \\
\hline \multicolumn{3}{|l|}{ Escherichia coli } \\
\hline TOP10 & $\begin{array}{l}\mathrm{F}^{-} \text {mcrA } \Delta(\text { mrr-hsdRMS-mcrBC) } \phi 80 l a c Z \Delta \mathrm{M} 15 \Delta \text { lacX74 deo } \mathrm{R} \text { rec } \mathrm{A} 1 \text { ara } 139 \Delta(\text { ara- } \\
\text { leu }) 7697 \text { gal } \mathrm{U} \text { galK } r p s \mathrm{~L}\left(\mathrm{Str}^{\mathrm{r}}\right) \text { end } \mathrm{A} 1 \text { nup } \mathrm{G}\end{array}$ & Invitrogen, Carlsbad, CA, U.S.A. \\
\hline \multicolumn{3}{|c|}{ Xanthomonas oryzae pv. oryzae } \\
\hline PXO99 A & $\begin{array}{l}\text { Azacytidine resistant derivative of Philippine race } 6 \text { strain PXO99, virulent to rice cultivars } \\
\text { IR24, IRBB7, and IRBB10 }\end{array}$ & Choi and Leach 1994 \\
\hline PXO99 ${ }^{\mathrm{A}} \mathrm{ME7}$ & $\begin{array}{l}\text { Previously unnamed marker exchange mutant of PXO99 }{ }^{\mathrm{A}} \text { with Tn5-gusAl insertion number } 7 \text {, } \\
\text { in } h r c U \text { (in the } h r p C \text { operon; Zhu et al. 2000, Fig. 1), type III secretion system-deficient, } \mathrm{Km}^{\mathrm{r}}\end{array}$ & Zhu et al. 2000 \\
\hline JXO1 & Japanese race 1 strain. Avirulent to IRBB2 & Yang and White 2004 \\
\hline \multicolumn{3}{|l|}{ X. oryzae pv. oryzicola } \\
\hline BLS256 & Philippines isolate & J. Leach \\
\hline BLS303 & Philippines isolate & J. Leach \\
\hline${\mathrm{BLS} 303 \mathrm{hrcC}^{-}}^{-}$ & BLS303 with insertion of pTOPO $h r c C 174-781$ in $h r c C$, TTSS-deficient, $\mathrm{Km}^{\mathrm{r}}$ & This study \\
\hline \multicolumn{3}{|c|}{ 5е } \\
\hline pBluescript II KS(+) & Cloning vector, $\mathrm{Ap}^{\mathrm{r}}$ & Stratagene, La Jolla, CA, U.S.A. \\
\hline $\mathrm{pCH} 43$ & $\begin{array}{l}\text { pUC118 carrying } 4.79-\mathrm{kb} \text { fragment of } X \text {. oryzae pv. oryzae PXO86 genome containing } \\
\text { avrXa10 and flanking DNA, } \mathrm{Ap}^{\mathrm{r}}\end{array}$ & Hopkins et al. 1992 \\
\hline pCRBluntII & TOPO cloning vector, $\mathrm{Km}^{\mathrm{r}}$ & Invitrogen \\
\hline pDD62 & Derivative of pVSP1 (Van Der Bij et al. 1996), broad host range, high copy, $\mathrm{Km}^{\mathrm{r}}$ & Mudgett et al. 2000, B. Staskawicz \\
\hline pHM1 & $\begin{array}{l}\text { Derivative of pRI } 40 \text { (Innes et al. 1988) containing multiple cloning site of pUC19, broad } \\
\text { host range, low copy, } \mathrm{Sp}^{\mathrm{r}}\end{array}$ & R. Innes \\
\hline pHMavrBs3 & pHM1 carrying avrBs 3 with FLAG epitope tag near $3^{\prime}$ end, fused with $l a c Z$ promoter, $\mathrm{Sp}^{\mathrm{r}}$ & Zhu et al. 1998 \\
\hline pHMavrXa10 & pHM1 carrying avrXa10 with FLAG epitope tag near $3^{\prime}$ end, fused with $l a c Z$ promoter, $\mathrm{Sp}^{\mathrm{r}}$ & Zhu et al. 1998 \\
\hline pHMavrXa7 & pHM1 carrying avrXa7 with FLAG epitope tag near $3^{\prime}$ end, fused with $l a c Z$ promoter, $\mathrm{Sp}^{\mathrm{r}}$ & Yang et al. 2000 \\
\hline pKEB26 & $\begin{array}{l}\text { pDD62 carrying avrXa10 with native promoter, downstream of and oriented with lacZ } \\
\text { promoter of pDD62, } \mathrm{Km}^{\mathrm{r}}\end{array}$ & This study \\
\hline pKEB27 & pDD62 containing the 30-bp BamHI to XhoI fragment of pBluescript II KS(+), $\mathrm{Km}^{\mathrm{r}}$ & This study \\
\hline pKEB45 & $\begin{array}{l}\text { Similar to pHMAvrXa10, but with a 1,232-bp fragment encoding residues } 2 \text { to } 406 \text { of Cya } \\
\text { inserted in-frame in the SalI site at bp } 2,945 \text { of avrXa10 }\end{array}$ & This study \\
\hline pMJH20 & Source of DNA fragment encoding residues 2 to 406 of Cya, $\mathrm{Ap}^{\mathrm{r}}$ & Miao et al. 1999 \\
\hline pTOPOhrcC174-781 & $\begin{array}{l}\text { pCRBluntII containing bp } 174 \text { to } 781 \text { (608 bp) of the } h r c C \text { open reading frame of } X \text {. oryzae } \\
\text { pv. oryzicola BLS256, } \mathrm{Km}^{\mathrm{r}}\end{array}$ & This study \\
\hline pZWavrXa10 & $\begin{array}{l}\text { avrXa10 cloned into pBluescript II KS+, downstream of and oriented with the lacZ } \\
\text { promoter. }\end{array}$ & Zhu et al. 1998 \\
\hline
\end{tabular}

\footnotetext{
${ }^{\mathrm{z}} \mathrm{Ap}=$ ampicillin, $\mathrm{Km}=$ kanamycin, and $\mathrm{Sp}=$ spectinomycin.
} 
and AvrXa10 to render $X$. oryzae pv. oryzicola avirulent in rice is not likely due to a failure in delivery.

$X$. oryzae pv. oryzicola and $X$. oryzae pv. oryzae deliver equivalent amounts

of an AvrXa10:Cya fusion protein into rice cells.

To determine whether a quantitative difference in the abilities of $X$. oryzae pv. oryzicola and $X$. oryzae pv. oryzae to deliver AvrXa10 into rice cells could account for the lack of HR to $X$. oryzae pv. oryzicola expressing avrXa10, Cya was used as a reporter. A construct similar to $\mathrm{pHMavrXa10} \mathrm{but} \mathrm{encoding}$ a fusion of Cya to the C-terminus of AvrXa10, pKEB45 (Table 1 ), was made and introduced into $X$. oryzae pv. oryzicola BLS303 and X. oryzae pv. oryzae PXO99A. As controls, pKEB45 was also introduced into corresponding TTSS-defi-
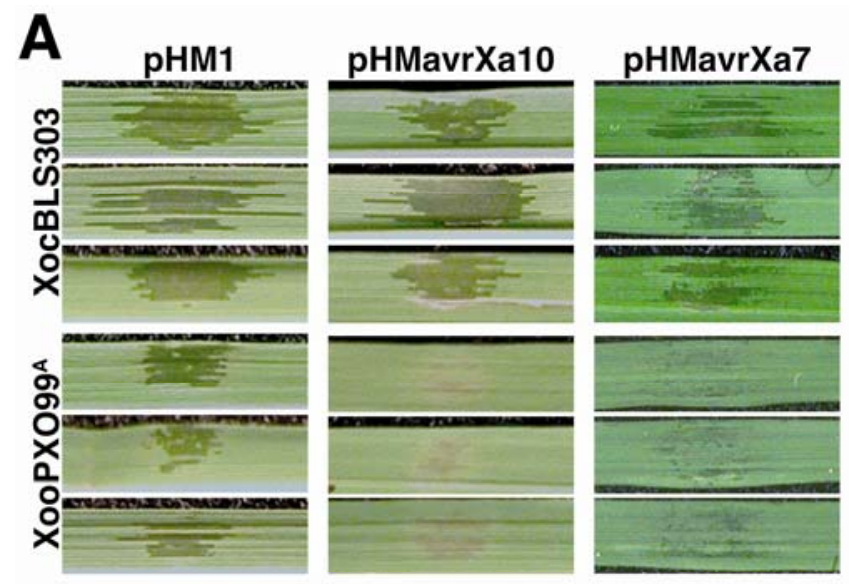

B

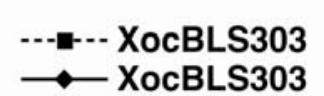

(pHMavrXa10)

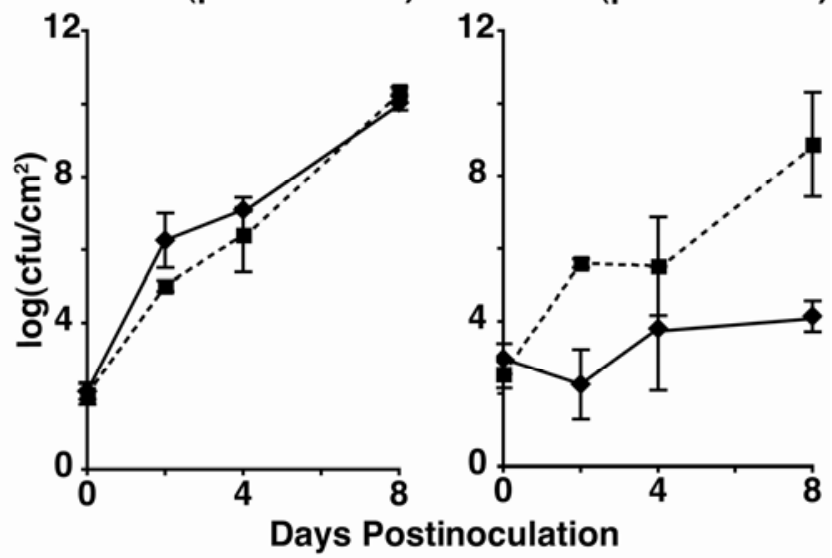

Fig. 1. Neither avrXal0 nor avrXa7 in plasmid pHM1 renders Xanthomonas oryzae pv. oryzicola avirulent to rice plants containing a corresponding $R$ gene. A, Symptoms at two days following syringe infiltration of $X$. oryzae pv. oryzicola (Xoc) BLS303 or X. oryzae pv. oryzae $\mathrm{PXO} 99^{\mathrm{A}}$ carrying either $\mathrm{pHM} 1$ or $\mathrm{pHMavrXa10}$ into leaves of rice cv. IRBB10, which carries the $\mathrm{Xa10}$ resistance gene, or of the same strains carrying pHMavrXa7 into leaves of IRBB7, which carries Xa7. Virulent strains cause dark lesions water-soaked in appearance. Avirulent strains induce the hypersensitive reaction, visible as lighter brown collapsed tissue. B, Plots of bacterial populations in leaves over eight days for BLS303 and BLS303(pHMavrXa10), compared with PXO99 $^{\mathrm{A}}$ and PXO99 ${ }^{A}(\mathrm{pHMavrXa10)}$, inoculated to rice cv. IRBB10 by syringe infiltration. Capped, vertical bars represent standard deviation of values (CFU per square centimeter of leaf) from three samples. Experiments were repeated three times with similar results. cient mutant strains BLS303hrc $C^{-}$and PXO99 ${ }^{\mathrm{A}} \mathrm{ME7}$ (Table 1), and the empty vector pHM1 was introduced into BLS303 and PXO99 ${ }^{\mathrm{A}}$. The resulting transformants were inoculated to leaves of rice cv. IR24, which lacks Xa10, and after 8 h, Cya activity in the inoculated tissue was assessed, using a quantitative immunoassay to measure cyclic AMP levels (discussed below). Inoculation of BLS303(pKEB45) or PXO99 $(\mathrm{pKEB} 45)$ resulted in equivalent, high levels of cyclic AMP relative to those resulting from inoculation of the TTSS-deficient strains or the strains carrying $\mathrm{pHM} 1$, indicating that both $X$. oryzae $\mathrm{pv}$. oryzicola and $X$. oryzae pv. oryzae deliver AvrXa10 into rice cells in similar amounts (Fig. 3).

\section{Coinoculated $X$. oryzae pv. oryzicola inhibits the rice HR} to avirulent $X$. oryzae pv. oryzae

in a TTSS-dependent fashion.

The above results suggested that $X$. oryzae pv. oryzicola might specifically interfere with resistance responses to Avr proteins in rice. To test this idea, IRBB10 rice plants were coinoculated with wild-type $X$. oryzae pv. oryzicola BLS303 and $X$. oryzae pv. oryzae $\mathrm{PXO} 99^{\mathrm{A}}(\mathrm{pHMavrXa10)}$ at a $1: 1$ ratio. As with strains of $X$. oryzae pv. oryzicola inoculated alone, HR did not occur (Fig. 4A). The same result was observed upon coinoculating plants of cv. IRBB7 with BLS303 and PXO99 ${ }^{\mathrm{A}}$ (pHavrXa7) or cv. IRBB2, containing $\mathrm{Xa2}$, with BLS303 and X. oryzae pv. oryzae JXO1 (Table 1), which is avirulent to plants containing $X a 2$ (data not shown). At the same time, $X$. oryzae pv. oryzae $\mathrm{PXO} 99^{\mathrm{A}}(\mathrm{pHMavrXa10)}$ mixed at the same ratio with the virulent parental strain $\mathrm{PXO} 99^{\mathrm{A}}$ and coinoculated in the same manner to IRBB10 plants did elicit an HR (Fig. 4A) that was indistinguishable in extent and timing from that elicited by PXO99 ${ }^{A}$ (pHMavrXa10) alone (Fig. 1A). Symptoms over time were compared among IRBB10 leaves inoculated with $X$. oryzae pv. oryzae $\mathrm{PXO} 99^{\mathrm{A}}(\mathrm{pHMavrXa10),} X$. oryzae pv. oryzicola BLS303, and a 1:1 mixture of the two (Fig. 4B). One day after inoculation, incomplete but discernible HR of infiltrated tissue was apparent for $X$. oryzae pv. oryzae PXO99 ${ }^{\mathrm{A}}$ (pHMavrXa10) only; the coinoculated tissue and tissue inoculated with $X$. oryzae pv. oryzicola BLS303 alone showed no symptoms. Water-soaking became visible in the tissue infiltrated with the coinoculum and with $X$. oryzae pv. oryzicola BLS303 after two days and to a similar extent. The earlier appearance of HR compared with water-soaking and the lack of HR by day 1 following coinoculation indicates that water-soaking is not masking the HR in this experiment. This observation provides evidence that $X$. oryzae pv. oryzicola actively interferes

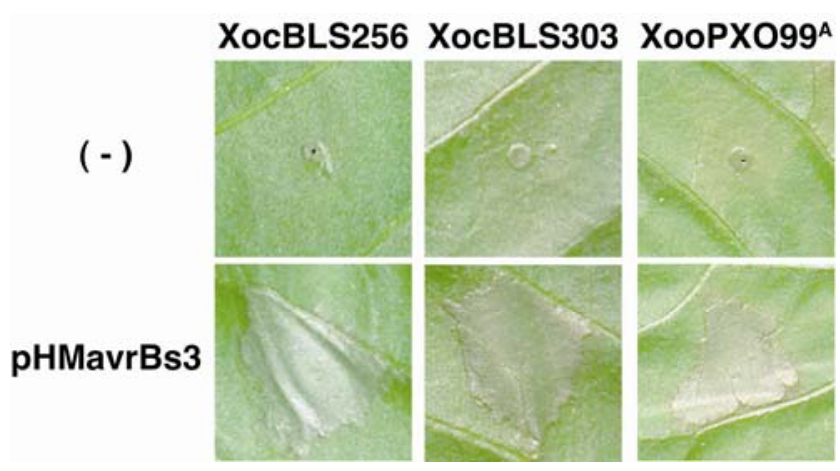

Fig. 2. Xanthomonas oryzae pv. oryzicola (Xoc) strains BLS256 and BLS303 and X. oryzae pv. oryzae (Xoo) PXO99 ${ }^{\mathrm{A}}$ transformed with avrBs3 induce the hypersensitive reaction (HR) of pepper plants carrying the $B s 3$ gene. Leaves of pepper cv. ECW30R were infiltrated using a syringe with the indicated strains carrying no plasmid (-) or pHMavrBs3, encoding AvrBs3. Photographs were taken two days after inoculation. HR is apparent as light brown collapsed tissue. 
with rice resistance responses to the selected Avr proteins and that the interference takes place following secretion of these proteins from the bacterial cell.

We next determined whether the inhibition of rice HR to avirulent $X$. oryzae pv. oryzae depends on the TTSS of $X$. oryzae pv. oryzicola by using BLS303hrc C. This strain was nonpathogenic and failed to prevent an $\mathrm{HR}$ when coinoculated with PXO99 ${ }^{\mathrm{A}}$ (pHMavrXa10) (Fig. 4A). Together, the results support a model in which $X$. oryzae pv. oryzicola specifically prevents or suppresses rice defense responses to avirulence

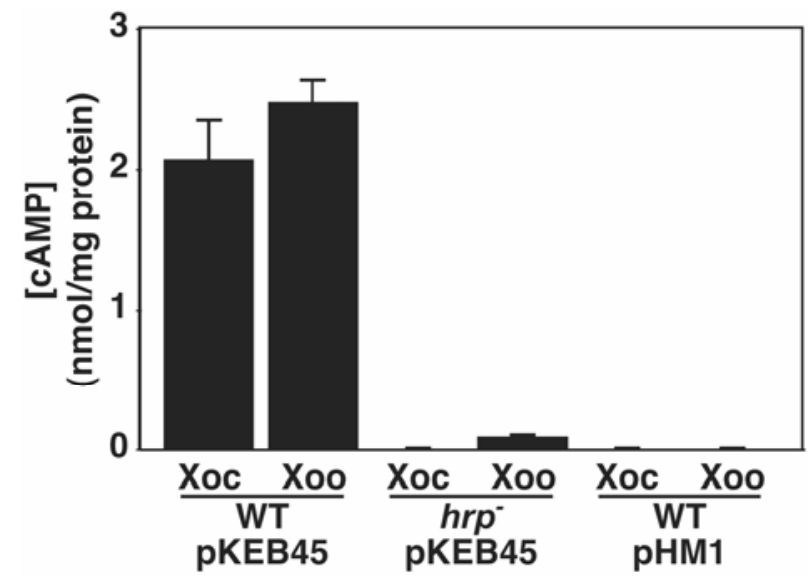

Fig. 3. Xanthomonas oryzae pv. oryzicola (Xoc) and X. oryzae pv. oryzae (Xoo) deliver equivalent amounts of an AvrXa10:Cya fusion protein into rice cells. Shown are mean cyclic AMP concentrations for three technical replicates of two replicate samples each of leaves of rice cv. IR24, which lacks Xa10, $8 \mathrm{~h}$ following syringe infiltration of wild-type (WT) or Hrpdeficient $\left(h r p^{-}\right)$strains carrying either pKEB45 or the empty vector pHM1. pKEB45 is similar to pHMavrXa10 but contains an in-frame, $3^{\prime}$ fusion to avrXa10 of a fragment encoding the calmodulin-dependent adenylate cyclase of Bordetella pertussis. Capped vertical bars represent standard deviation. This experiment was repeated three times with similar results. signals via the plant intracellular activity of one or more endogenous type III effector proteins.

\section{$X$. oryzae pv. oryzicola defense inhibition is quantitative.}

Coinoculations of IRBB10 plants were carried out using a series of different ratios of $X$. oryzae pv. oryzae PXO99 ${ }^{\mathrm{A}-}$ (pHMavrXa10) to $X$. oryzae pv. oryzicola BLS303. The HR occurred at the highest ratios, indicating that HR inhibition by $X$. oryzae pv. oryzicola in this context is quantitative (Fig. 5A, panel 1). The same series of coinoculations of PXO99 ${ }^{\mathrm{A}-}$ (pHMavrXa10) was also carried out with the virulent $X$. oryzae pv. oryzae parental strain $\mathrm{PXO}^{\mathrm{A}}$. At relatively low ratios of avirulent to virulent bacteria, X. oryzae pv. oryzae also inhibited the HR (Fig. 5A, panel 3). At the lowest ratio tested, symptoms over time were similar to those resulting from the inoculation of a 1:1 mixture of avirulent $X$. oryzae pv. oryzae and $X$. oryzae pv. oryzicola shown in Figure 4B (data not shown). Thus $X$. oryzae pv. oryzae also quantitatively inhibits rice defense but, apparently, less effectively than $X$. oryzae pv. oryzicola. To assess whether the transition from watersoaking to $\mathrm{HR}$ as ratios of avirulent to virulent strain increased correlated with an Xa10-dependent suppression of bacterial population growth, populations of $\mathrm{PXO} 99^{\mathrm{A}}$ (pHMavrXa10) were measured (by plating with selection for the plasmid) over time following coinoculation with BLS303 or PXO99 ${ }^{\mathrm{A}}$ at selected ratios both in cv. IRBB10 and in cv. IR24 (Fig. 5B). For PXO99 ${ }^{\mathrm{A}-}$ (pHMavrXa10) coinoculated with PXO99 ${ }^{\mathrm{A}}$, reduced growth in IRBB10 relative to IR24 was evident at low ratios, but the relative reduction in growth became greater with increasing proportions of the avirulent strain, consistent with a weak defense-inhibitory effect of PXO99 ${ }^{\mathrm{A}}$. In coinoculations with BLS303, populations of $\mathrm{PXO} 99^{\mathrm{A}}$ (pHMavrXa10) followed similar patterns of growth in IRBB10 and IR24 at all but the highest ratio tested, at which significantly reduced population growth in IRBB10 relative to IR24 was observed (data not shown). The overall growth patterns in IR24 of PXO99 ${ }^{\mathrm{A}}$ (pHMavrXa10) coinoculated with BLS303, however,
A

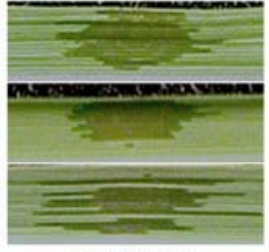

PXO99A (pHMavrXa10) +BLS303

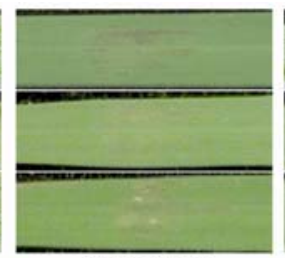

$\mathrm{PXO99}^{\mathrm{A}}$ (pHMavrXa10) + PXO99A $^{\mathrm{A}}$

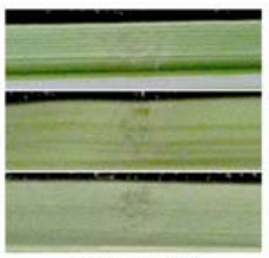

PXO99A (pHMavrXa10) $+\mathrm{BLS} 303 \mathrm{hrCC}^{-}$

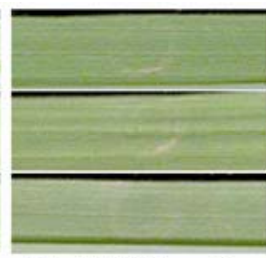

BLS303hrcC-
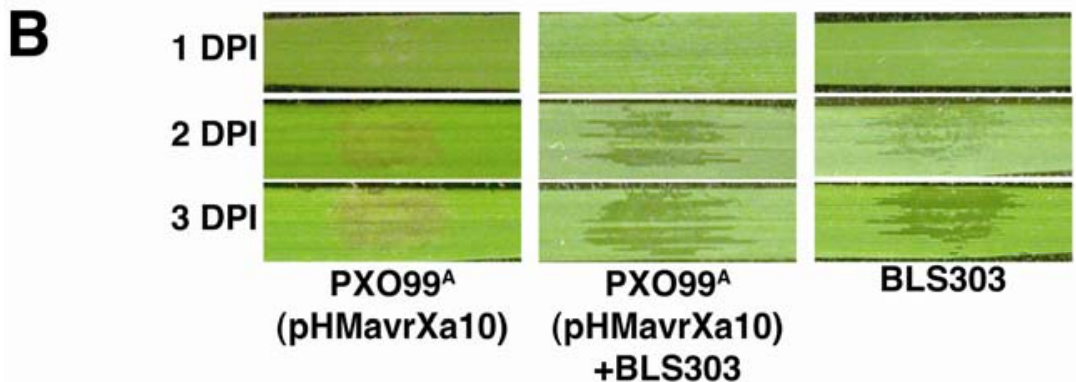

BLS303

Fig. 4. Xanathomonas oryzae pv. oryzicola (Xoc) inhibits hypersensitive reaction (HR) of rice cv. IRBB10 to X. oryzae pv. oryzae (Xoo) carrying avrXa10 in a type III secretion-dependent manner. A, Leaves 2 days following inoculation with the indicated strains suspended individually to an optical density at 600 $\mathrm{nm}\left(\mathrm{OD}_{600}\right)=1.0$ and infiltrated together at a 1:1 ratio or (for BLS303 hrc $C^{-}$) suspended to an OD $600=0.5$ and infiltrated alone. B, Leaves 1,2 , and 3 days postinoculation (DPI) with the indicated strains or strain mixture, prepared and infiltrated as in A. Dark lesions appearing water-soaked are typical for virulent $X$. oryzae pv. oryzicola and $X$. oryzae pv. oryzae strains. Light-brown collapsed tissue indicates the HR. A lighter, tan-colored ring visible in some panels is the result of wounding with the syringe. 
A
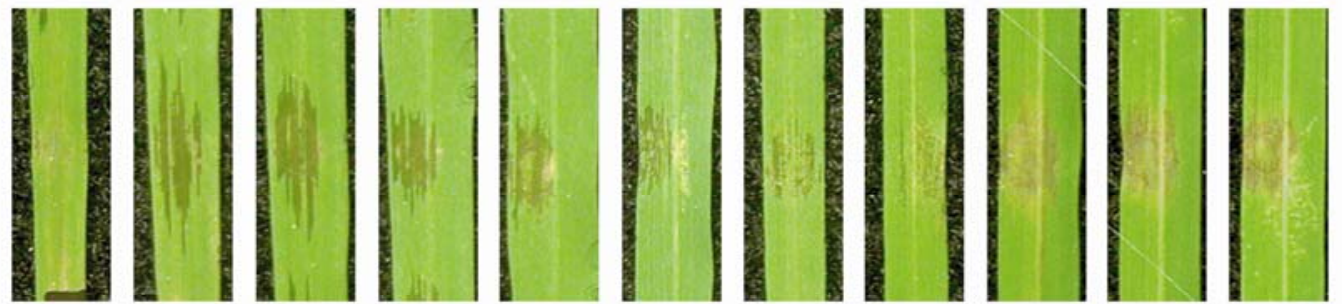

XooPX099A

(pHMavrXa10)

XocBLS303
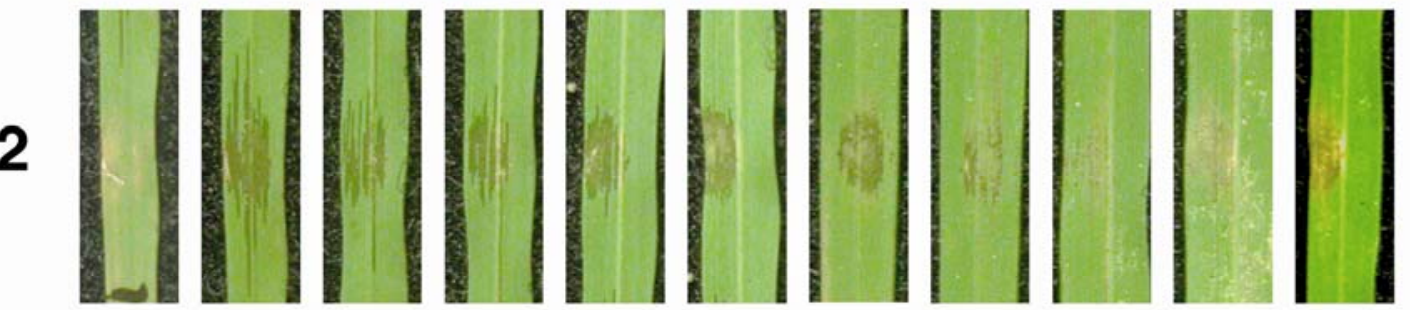

XooPXO99'

(pKEB26)

XocBLS303
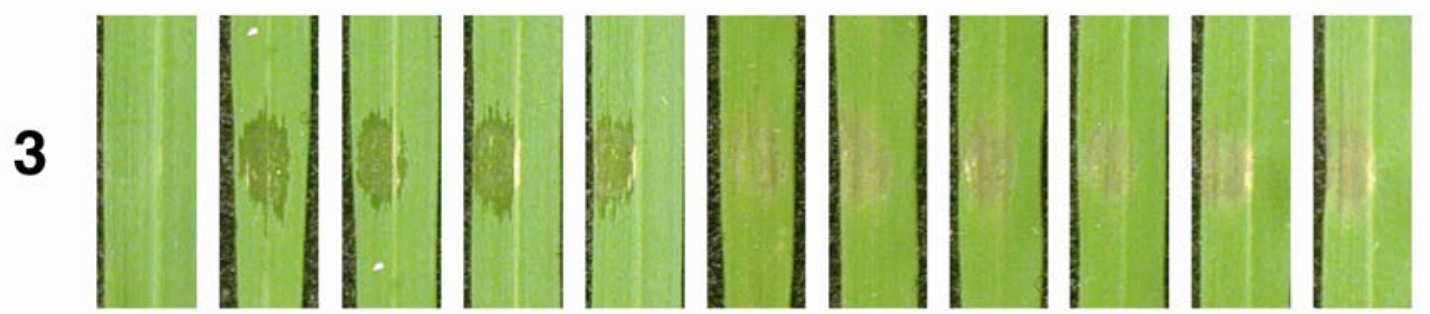

XooPXO99A

(pHMavrXa10)

XоOPX099 ${ }^{A}$
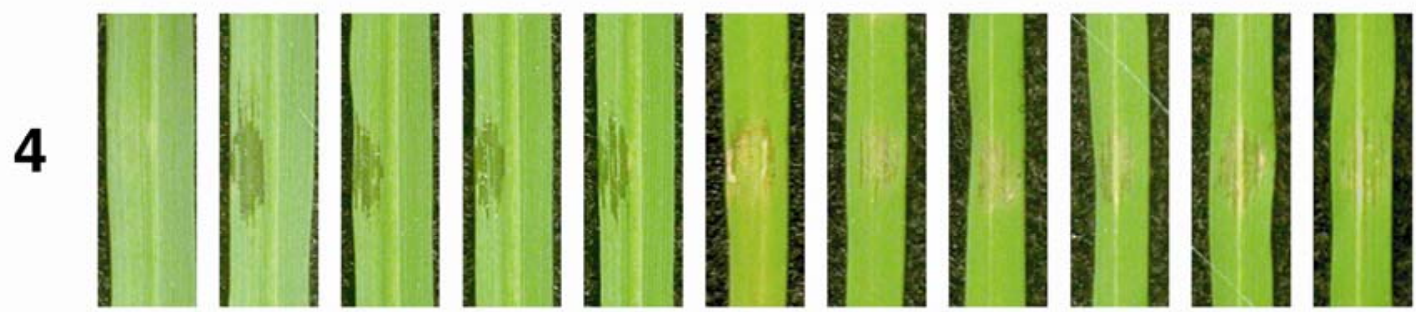

XooPXO99A

(pKEB26)

XooPX099A

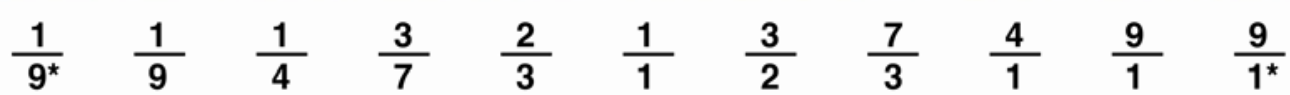

Ratio
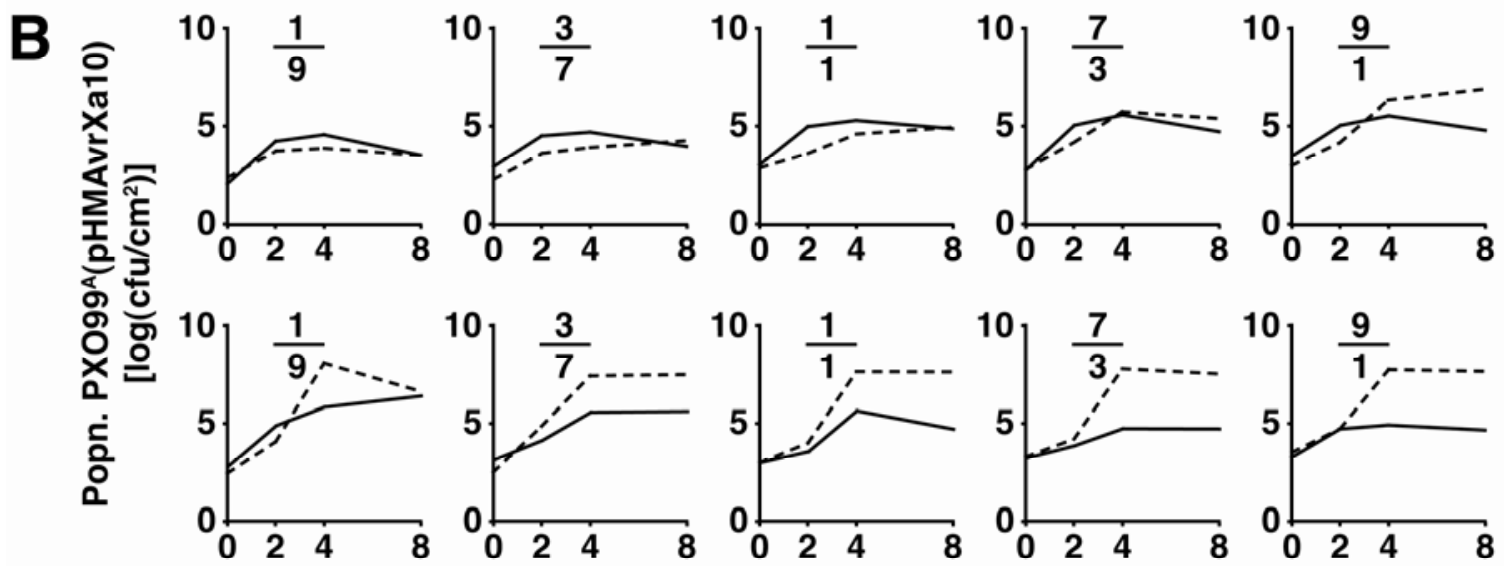

XooPXO99A

(pHMavrXa10)

XocBLS303
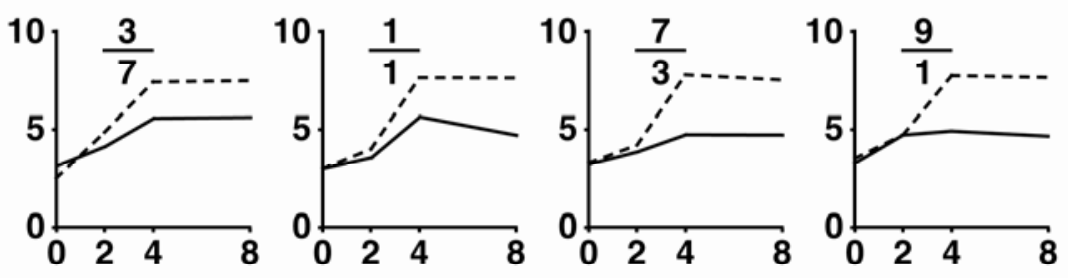

XooPX099A

(pHMavrXa10) XoOPXO99 ${ }^{A}$

Days Postinoculation

- - - IR24

- IRBB10

Fig. 5. Xanathomonas oryzae pv. oryzicola (Xoc) inhibits hypersensitive reaction (HR) of rice cv. IRBB10 to X. oryzae pv. oryzae (Xoo) carrying avrXa10 in a quantitative manner unaffected by copy number of the avrXa10 construct, and inhibition activity is weakly conserved in $X$. oryzae pv. oryzae. A, Leaves 3 days after inoculation with mixtures of X. oryzae pv. oryzicola BLS303 or X. oryzae pv. oryzae PXO99 ${ }^{\mathrm{A}}$ with PXO99 ${ }^{\mathrm{A}}$ carrying either pHMavrXa10 (panels 1 and 3) or pKEB26 (panels 2 and 4). Strains were suspended individually to an optical density at $600 \mathrm{~nm}=0.5$ and were mixed at the indicated ratios before infiltration. An asterisk indicates that the corresponding strain suspension was replaced with an equivalent volume of water. Note that, at the minimum concentration tested in coinoculations, the avirulent X. oryzae pv. oryzae strain by itself elicited a robust HR. B, Plots of populations of PXO99 $(\mathrm{pHMavrXa10)}$ in rice cv. IRBB 10 (solid lines) or cv. IR24 (dashed lines) over 8 days following coinoculation in the indicated ratios with BLS303 or PXO99 ${ }^{\mathrm{A}}$. 
were similar to growth patterns in IRBB10 of $\mathrm{PXO}^{\mathrm{A}-}$ (pHMavrXa10) coinoculated with $\mathrm{PXO}^{\mathrm{A}}{ }^{\mathrm{A}}$, suggesting that BLS303, which multiplies faster than PXO99 ${ }^{\mathrm{A}}$ in susceptible rice (Fig. 1B), may have directly or indirectly suppressed population growth of $\mathrm{PXO}^{\mathrm{A}}$ (pHMavrXa10) to a degree similar to, and masking the potential effect of, the $R$ gene. In neither experiment did a divergence in growth pattern correlate strictly with the appearance of the HR, though the divergence followed the same overall trend as the HR, increasing with increasing ratios of avirulent to virulent strains.

\section{Expression of avrXa10 from a higher-copy plasmid in $X$. oryzae pv. oryzicola leads to avirulence.}

Plasmid pKEB26 consists of the avrXal0 gene with its native promoter in tandem with the lacZ promoter (as in pHMavrXa10) in the vector pDD62 (Table 1), which is a higher copy-number plasmid than $\mathrm{pHMavrXa10.} \mathrm{We} \mathrm{reasoned}$ that pKEB26 would permit higher levels of avrXa10 expression and possibly alter the balance between the secretion of AvrXa10 and one or more presumed inhibitors. In fact, inoculation of transformants of either $X$. oryzae pv. oryzicola BLS303 or BLS256 carrying pKEB26 induced HR on IRBB10 plants, just as the control strain $\mathrm{PXO} 99^{\mathrm{A}}(\mathrm{pHMAvrXa10)}$ or PXO99 ${ }^{\mathrm{A}}$ (pKEB26), which was also tested (Fig. 6 and data not shown). Although this result contradicts the result with pHMavrXa10, the induction of an HR by $X$. oryzae pv. oryzicola strains carrying pKEB26 confirms that this pathovar can

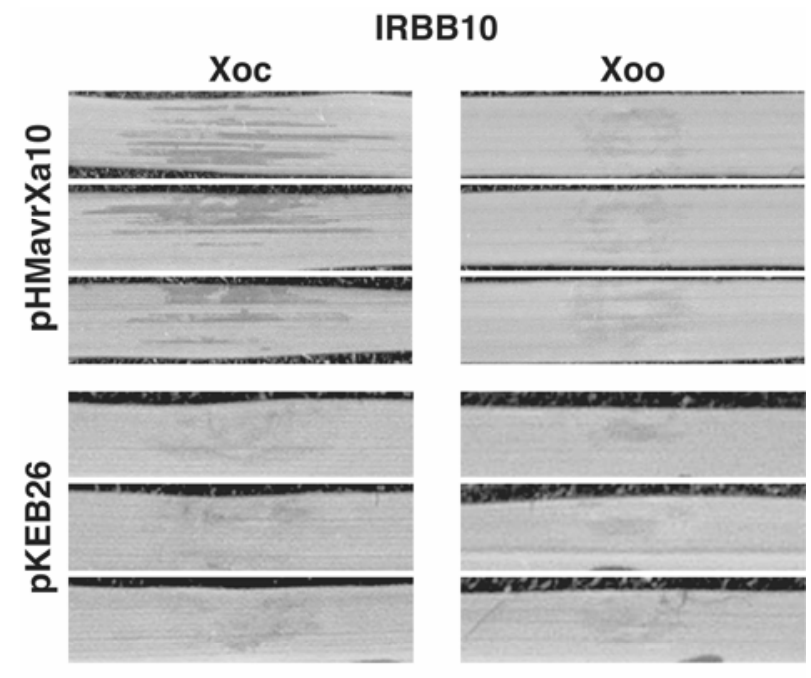

IR24
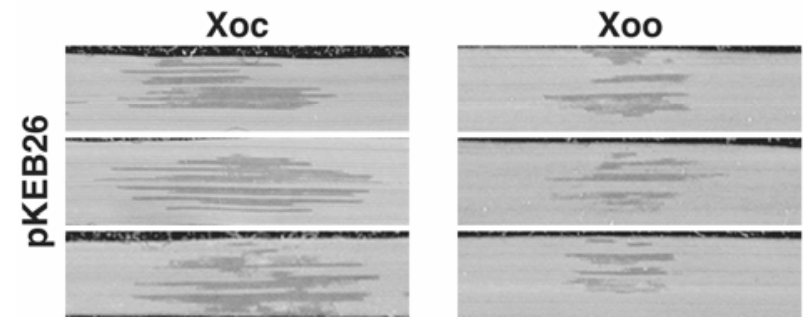

Fig. 6. Expression of avrXa10 from a high-copy number plasmid renders Xanthomonas oryzae pv. oryzicola avirulent to rice plants containing Xa10. Leaves of rice cv. IRBB10 were inoculated by syringe infiltration with X. oryzae pv. oryzicola (Xoc) BLS303 or X. oryzae pv. oryzae (Xoo) PXO99 $^{\mathrm{A}}$ carrying pHMavrXa10 or the high-copy number equivalent pKEB26, as indicated. As a control, cv. IR24, lacking Xa10, was inoculated with the strains carrying pKEB26, as shown. Leaves were photographed 2 days following inoculation. Virulent strains cause dark lesions water-soaked in appearance. Avirulent strains induce the lighter colored hypersensitive reaction. deliver AvrXa10 into rice cells and provides evidence for a stoichiometric relationship between AvrXa10 and one or more presumed inhibitors in determining the plant response. AvrXa10 expression from pKEB26 might result in a simple increase in the proportion of AvrXa10 in the plant cell, or AvrXa10 may competitively impede secretion of other type III effectors of $X$. oryzae pv. oryzicola, including one or more presumed inhibitors. While these possibilities could not be distinguished phenotypically in $X$. oryzae pv. oryzicola due to the lack of an HR in rice, an experiment was performed to determine if AvrXa10 expression from pKEB26 blocks avrXa7-mediated HR elicitation by $X$. oryzae pv. oryzae. pHMavrXa7 was introduced into $X$. oryzae pv. oryzae PXO99 ${ }^{\AA}$ containing pKEB26, and the resulting strain PXO99 $(\mathrm{pKEB} 26$, pHMavrXa7) and appropriate control strains were inoculated to IRBB7 plants and IRBB10 plants. PXO99 ${ }^{\mathrm{A}}(\mathrm{pKEB} 26$, pHMavrXa7) elicited an HR on both IRBB10 and IRBB7 (Fig. 7). Thus, expression of avrXal0 from pKEB26 does not block type III secretion to an extent that prevents signaling by avrXa7. Notably also, pKEB26 did not interfere with the abilities of either BLS303 or PXO99 ${ }^{\mathrm{A}}$ to cause water-soaking in cv. IR24 (Fig. 6), indicating that it does not impede traffic necessary for virulence. Coinoculation experiments at different ratios were also conducted using PXO99 ${ }^{\mathrm{A}}$ carrying pKEB26 as the avirulent strain, and no discernible difference was observed in the ability of $X$. oryzae pv. oryzicola BLS303 to inhibit HR elicitation by this strain and to inhibit HR elicitation by PXO99A (pHMavrXa10) (Fig. 5A, panels 1 and 2). Also, as for $X$. oryzae pv. oryzicola, no difference was observed in the ability of $X$. oryzae pv. oryzae $\mathrm{PXO} 99^{\mathrm{A}}$ to inhibit the HR elicited by $\mathrm{PXO}^{\mathrm{A}}$ (pKEB26) or PXO99 ${ }^{\mathrm{A}}$ (pHMavrXa10) (Fig. 5A, panels 3 and 4). Thus, inhibition is overcome when pKEB26 is in $X$. oryzae pv. oryzicola but not when it is in a coinoculated $X$. oryzae pv. oryzae strain.

\section{DISCUSSION}

$X$. oryzae pv. oryzae and $X$. oryzae pv. oryzicola each carry multiple members of the avrBs3/PthA gene family (Yang et al. 2000). Defining the functions of these genes will advance our understanding of the molecular basis of bacterial blight and of bacterial leaf streak of rice and ultimately contribute to our ability to more effectively control these and other diseases caused by xanthomonads. In $X$. oryzae pv. oryzae, different members of the family function as major virulence determinants in different strains (Yang and White 2004). The only isolated avirulence determinants from $X$. oryzae pv. oryzae are members of the family, avrXa7 and avrXa10, and the recently

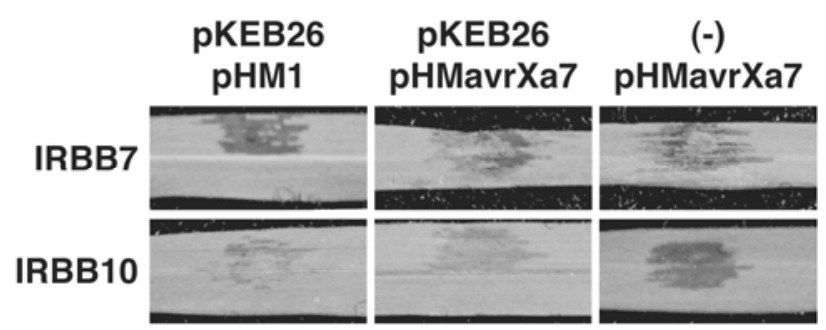

Fig. 7. Expression of avrXal0 from the high-copy number plasmid pKEB26 does not block signaling mediated by avrXa7. Leaves of rice $\mathrm{cv}$. IRBB7 and cv. IRBB10 as a control were inoculated by syringe-infiltration with Xanthomonas oryzae pv. oryzae PXO99 ${ }^{\mathrm{A}}$ containing pKEB26 and pHM1, pKEB26 and pHMavrXa7, or pAvrXa7 alone, as indicated. Leaves were photographed 4 days following inoculation. Note that the hypersensitive reaction (HR) of IRBB7 triggered by the presence of pHMavrXa7 is less pronounced than the HR of IRBB10 triggered by pKEB26 but is not blocked by the presence of pKEB26. 
cloned avrXa27 (Gu et al. 2005). One might expect similar functions for the avrBs3-like genes in X. oryzae pv. oryzicola. Evidence suggests, however, that the genes in the two pathogens may function differently. First, an avrBs3-like gene that complements mutations in the homologous major virulence determinant genes of $X$. oryzae pv. oryzae could not be recovered from X. oryzae pv. oryzicola (Yang and White 2004). Second, host genes induced by $X$. oryzae pv. oryzae in a manner dependent on avrBs3-like genes in the pathogen are not induced by $X$. oryzae pv. oryzicola (A. Sugio and F. White, unpublished results). Also, curiously, no endogenous avr/R gene combination has been described for $X$. oryzae pv. oryzicola and rice. Experiments were, therefore, designed to first determine if $a v r$ genes of the $a v r B s 3 / p t h A$ family from $X$. oryzae pv. oryzae would operate in X. oryzae pv. oryzicola. Specifically, avrXa7 and avrXa10 were introduced into $X$. oryzae pv. oryzicola, and the resulting strains were tested for avirulence in rice plants with corresponding $R$ genes. Neither gene conferred avirulence in either of two strains of $X$. oryzae pv. oryzicola. Further investigation led to the unexpected discovery that $a v r X a 7$ and $a v r X a 10$ failed to function because $X$. oryzae pv. oryzicola inhibits $R$ gene-mediated defense in rice, putatively via the action of one or more endogenous type III effectors.

Several lines of evidence support this conclusion. First, the lack of an effective resistance response in rice was not likely due to a failure of $X$. oryzae pv. oryzicola to express and deliver AvrXa7 and AvrXa10, since the same strains transformed with an equivalent $a v r B s 3$ construct could induce a $B s 3$-dependent $\mathrm{HR}$ in pepper and because $X$. oryzae pv. oryzicola could deliver an AvrXa10:Cya fusion protein to rice cells in an amount equivalent to that delivered by $X$. oryzae pv. oryzae. Second, coinoculated $X$. oryzae pv. oryzicola blocked HR to avirulent $X$. oryzae pv. oryzae and this ability depended on a functional $X$. oryzae pv. oryzicola TTSS, indicating that one or more $X$. oryzae pv. oryzicola type III effectors likely interfere with resistance from within the plant cell. Third, inhibition of rice HR to $X$. oryzae pv. oryzae expressing AvrXa10 by coinoculated $X$. oryzae pv. oryzicola could be overcome by increasing the proportion of the avirulent $X$. oryzae pv. oryzae strain, consistent with the notion that inhibition depends on the activity of a type III-secreted protein or proteins that can be overwhelmed by greater amounts of the elicitor. Also, expression of $a v r X a 10$ from a high-copy number plasmid in X. oryzae pv. oryzicola resulted in HR, confirming the ability of $X$. oryzae pv. oryzicola to deliver this protein in rice and further suggesting a stoichiometric effect in determining the rice response.

A number of observations bear on whether inhibition involves blocking recognition of Avr signals, dampening of downstream signaling, or suppression of responses. In this study, $X$. oryzae pv. oryzicola prevented rice defense triggered by distinct Avr proteins, suggesting that inhibition might be targeting processes downstream of recognition. However, these effectors are structurally similar; an inhibitor might interfere similarly with recognition of either protein. In coinoculations, $X$. oryzae pv. oryzicola also blocked Xa2-mediated HR to X. oryzae pv. oryzae, but it is not known whether the corresponding avirulence signal is like AvrXa7 and AvrXa10. Failure of X. oryzae pv. oryzicola to inhibit the AvrBs3-dependent response in pepper suggests that an inhibitor does not target the Avr proteins directly. Inhibition could be directed at shared structures in the $\mathrm{R}$ proteins or occur via modification of a common target of the Avr proteins that is involved in recognition of the Avr proteins (Kim et al. 2005). If inhibition targets signal transduction, failure to prevent $B s 3$-mediated response in pepper might be due to a difference in the $B s 3$ vs. the $X a 7$ and $X a 10$ pathways or divergence of shared signaling components between pepper and rice. If inhibition targets a component of resistance responses common to most or all $R$-gene pathways, it might be expected to inhibit defense in a plant closely related to rice, such as maize. This is not the case however, as $X$. oryzae pv. oryzicola induces HR in maize varieties carrying the Rxol gene. This induction is due to avrRxol, a gene distinct from the avrBs3/ pthA family that is conserved in all X. oryzae pv. oryzicola isolates examined (Zhao et al. 2004). Recently, transgenic rice carrying Rxol was shown to be resistant to $X$. oryzae pv. oryzicola (Zhao et al. 2005), favoring the idea that X. oryzae pv. oryzicola inhibits only certain pathways. On the other hand, Rxo1 may "trump" (Abramovitch and Martin 2005) X. oryzae pv. oryzicola by suppressing defense inhibition activity in its recognition of AvrRxo1 (could AvrRxo1 be the inhibitor?). To better define the process targeted for inhibition by $X$. oryzae pv. oryzicola, diverse $a v r / R$ pairs need to be tested. Cloning of one or more putative inhibitors and expression in avirulent $X$. oryzae pv. oryzae strains will best enable assays of the effect on different $R$ gene-mediated responses. An intriguing possibility is that members of the avrBs3/pthA family themselves function in defense inhibition.

A difference in the effect on defense inhibition of expressing avrXal0 from a high- vs. a low-copy plasmid in X. oryzae pv. oryzicola and expressing it in a high- vs. a low-copy plasmid in $X$. oryzae pv. oryzae coinoculated with $X$. oryzae pv. oryzicola suggested that there is no significant difference in the amount of secretion of avrXalO due to the different plasmids, but that expression of avrXal0 from the high-copy plasmid overcame inhibition in $X$. oryzae pv. oryzicola due to an effect on delivery of one or more putative inhibitors from the bacterium. The hypothesis that type III secretion is limiting and that overexpression of an effector can compromise delivery of other effectors remains to be tested conclusively, but it is consistent with observations in $X$. oryzae pv. oryzae that complementation of a mutation in a virulence determinant of the avrBs3/pthA family using a plasmid-borne clone often fails to fully restore virulence in quantitative assays (Bai et al. 2000; Yang and White 2004; Yang et al. 2000); this failure could be due to a reduction in secretion of other virulence factors. pKEB26 did not disrupt watersoaking on the susceptible rice cv. IR24 or prevent HR mediated by pHMavrXa7 in X. oryzae pv. oryzae, but the former observation was not quantitative and the latter might have been affected by the fact that $a v r X a 7$ itself was on a multi-, albeit low, copy plasmid. The HpaB protein, required for secretion of AvrBs3 and several other effectors (Buttner et al. 2004), provides an example of a possible ratelimiting factor for type III secretion.

Recent evidence suggests that diverse type III effectors contribute to virulence by inhibiting plant-defense responses (Abramovitch and Martin 2004; DebRoy et al. 2004; Metz et al. 2005). Our demonstration that $X$. oryzae pv. oryzicola inhibits $R$ gene-mediated defense in its host plant in a TTSSdependent manner supports the notion that defense inhibition is a general mechanism in bacterial pathogenesis of plants and an important function of the TTSS. Further, our results demonstrate that one pathogen can inhibit host defense against another, otherwise-avirulent pathogen in the same plant.

The quantitative nature of defense inhibition by $X$. oryzae pv. oryzicola suggests an intriguing question; aside from disabling basal immunity and crippling host resistance responses mediated by $R$ genes, might there be a role for defense inhibitors in modulation of cell death during disease development? $\mathrm{HR}$ is a rapid form of programmed cell death (PCD) associated with successful defense against pathogens. Yet some evidence suggests that necrogenic plant pathogens may rely on controlled elicitation of plant PCD to colonize plant tissues or to generate lesions to aid in pathogen dispersal (Brunings and Gabriel 2003; Greenberg and Yao 2004). If manipulation of 
PCD is involved in disease development, a role for some bacterial effectors might be to dampen PCD so that it occurs only to an extent that promotes pathogen exploitation of host tissues and survival. Whether this is indeed the case for $X$. oryzae pv. oryzicola, $X$. oryzae pv. oryzae, and other necrogenic pathogens remains to be explored.

Outbreaks of bacterial leaf streak can have devastating impact, but they are sporadic (Mew 1993). Quantitative resistance to $X$. oryzae pv. oryzicola exists in some rice varieties (Tang et al. 2000), and there may be yet-unknown native $R$ genes that prevent the disease from becoming more prevalent. Nevertheless, the ability of $X$. oryzae pv. oryzicola to inhibit host defense provides a plausible explanation for the lack of known rice $R$ genes for bacterial leaf streak.

Our results provide the first demonstration that $X$. oryzae pv. oryzicola depends on the TTSS for pathogenesis and the first formal demonstration that AvrXa10 is delivered to rice cells, both by $X$. oryzae pv. oryzae and X. oryzae pv. oryzicola. These findings suggest that the many avrBs3/pthA family members present in $X$. oryzae pv. oryzicola are, in fact, expressed and their products secreted. The roles of these genes in pathogen-host interaction remain an important target for research. In addition to virulence functions, one might predict that avirulence functions might be revealed by heterologous expression of the genes in $X$. oryzae pv. oryzae inoculated to differential rice cultivars.

Also to be considered, the ability of $X$. oryzae pv. oryzicola to block elicitation of the HR by coinoculated avirulent $X$. oryzae pv. oryzae implies that $R$ genes to bacterial blight and perhaps other diseases may not be effective when $X$. oryzae pv. oryzicola is infecting the plant. Further elucidation of rice defense inhibition by X. oryzae pv. oryzicola is therefore a priority as well. Such elucidation should lead to a better understanding of the role of plant defense inhibition in pathogenesis generally and could contribute to the development of new strategies for disease control that target the defense inhibition mechanism and, in the case of bacterial leaf streak, uncover useful gene-for-gene interactions.

\section{MATERIALS AND METHODS}

DNA manipulation.

Standard methods of DNA manipulation were carried out as described (Sambrook et al. 1989). Plasmids were isolated using the Wizard miniprep (Promega, Madison, WI, U.S.A.) and the HiSpeed midiprep (Qiagen, Valencia, CA, U.S.A.) kits. X. oryzae pv. oryzicola genomic DNA for polymerase chain reaction (PCR) was extracted using the DNeasy kit (Qiagen).

\section{Bacterial strains, plasmids, and culture conditions.}

The bacterial strains and plasmids used in this study are listed in Table 1. pHMavrXa10, pHMavrXa7, and pHMavrBs3 have been described in detail previously (Yang et al. 2000; Zhu et al. 1998). Briefly, pHMavrXa10 is avrXal0 cloned in pBluescript $\mathrm{KS}(+)$, such that it is downstream of and oriented with the lacZ promoter (making pZWavrXa10; Table 1), and inserted into pHM1 (opposite the $l a c Z$ promoter of that plasmid). The lacZ promoter is expressed constitutively in Xanthomonas spp. (Soby and Daniels 1996). A 24-bp sequence encoding the FLAG epitope (Brizzard et al. 1994) is inserted at an engineered SalI site near the $3^{\prime}$ end of the open reading frame of avrXa10. Replication in Xanthomonas spp. is directed by the origin of pHM1. pHMavrXa7 and pHMavrBs3 are identical to pHMavrXa10 except for the gene-specific sequence between the conserved SphI sites in the avr genes. pKEB26 was constructed as follows. The BamHI to XhoI fragment of the mul- tiple cloning site (MCS) of pBluescript II $\mathrm{KS}(+)$ (Table 1) was inserted between these sites in pDD62 (Table 1), creating pKEB27 with unique sites BamHI, EcoRI, EcoRV, HindIII, and XhoI in the MCS. The 4.8-kb EcoRI to HindIII fragment of pCH43 (Table 1), containing the avrXalO open reading frame and $252 \mathrm{bp}$ upstream, was then inserted between these sites in pKEB27, resulting in pKEB26. In pKEB26, avrXa10 is downstream of and oriented with the lacZ promoter of pKEB27. To construct pTOPOhrcC174-781, a 608-bp internal fragment (base pairs 174 to 781 ) of the $h r c C$ open reading frame was amplified from $X$. oryzae pv. oryzicola BLS256 genomic DNA by PCR, using primers SM20 (forward primer, 5'-CACCTTGACCCTGTGCGGCATT-3') and SM21 (reverse primer, 5'-TTTGTCCGCCAGCCAGTCCATC-3'), designed based on the $h r c C$ sequence of $X$. oryzae pv. oryzae (GenBank accession number AB115081). The PCR product was cloned in pCRBluntII by the TOPO cloning reaction (Invitrogen, Carlsbad, CA, U.S.A.). pKEB45 was constructed similarly to pHMavrXa10. First, a 1,232-bp fragment encoding residues 2 to 406 of Cya was amplified from plasmid pMJH20 (Table 1) with primers that add a SalI site on each end. This fragment was then inserted in the SalI site at base pair 2,945 of avrXa10 in pZWavrXa10 (Table 1). Finally, the resulting plasmid was, linearized using HindIII and was inserted into the HindIII site of pHM1. Escherichia coli was cultured in Luria-Bertani medium (Sambrook et al. 1989) at $37^{\circ} \mathrm{C}$. $X$. oryzae strains were grown in glucose yeast extract (GYE; $20 \mathrm{~g}$ of glucose and $10 \mathrm{~g}$ of yeast extract per liter) medium or nutrient broth yeast extract (NBY; Vidaver 1967) medium at $28^{\circ} \mathrm{C}$. Ampicillin $(100 \mu \mathrm{g} / \mathrm{ml})$, kanamycin $(25$ $\mu \mathrm{g} / \mathrm{ml})$, and spectinomycin $(100 \mu \mathrm{g} / \mathrm{ml})$ were added to growth media as appropriate for plasmid selection.

\section{Plasmid transformation.}

Plasmids were introduced by electroporation into E. coli cells supplied with pCRBluntII according to the manufacturer's protocol (Invitrogen) and into Xanthomonas cells as described previously (Tsuge et al. 2001). Transformation of Xanthomonas strains was confirmed by reisolation and transfer of plasmids to $E$. coli.

\section{Plant materials and inoculations.}

Rice plants of the Indica variety IR24 and its near-isogenic lines, IRBB2 containing $X a 2$, IRBB7 containing $X a 7$, and IRBB10 containing Xal0, were grown in LC-1 soil mixture (SunGRO, Bellevue, WA, U.S.A.) in a growth chamber under cycles of $12 \mathrm{~h}$ of light at $28^{\circ} \mathrm{C}$ and $12 \mathrm{~h}$ of dark at $25^{\circ} \mathrm{C}$. Fertilizer (Peters Professional, St. Louis) and iron chelate micronutrient (Becker Underwood, Ames, IA, U.S.A.) were applied with watering every 2 days at rates of 0.25 and $4.5 \mathrm{~g} /$ liter, respectively. Plants were inoculated at four weeks after sowing by infiltration of leaves with bacterial suspension using a needleless syringe (Schaad et al. 1996). Pepper plants of cv. ECW30R carrying the $B s 3$ resistance gene were grown in a standard potting mix in a greenhouse and were inoculated by syringe infiltration at six weeks. For inoculations, overnight bacterial cultures were washed twice and were resuspended with sterile $\mathrm{H}_{2} \mathrm{O}$. Unless otherwise indicated, strains inoculated individually were suspended to an optical density at 600 $\mathrm{nm}\left(\mathrm{OD}_{600}\right)=0.5$, and strains inoculated together were suspended to an $\mathrm{OD}_{600}=1.0$ before mixing. Following inoculation, plants were incubated at room temperature under constant fluorescent light in the laboratory.

\section{Bacterial population growth measurement.}

Infiltrated areas of rice leaves were removed with a number 1 cork borer and were ground in liquid nitrogen in $1.5-\mathrm{ml} \mathrm{mi-}$ 
crocentrifuge tubes by using a plastic pestle (Kontes pellet pestle; Kontes, Vineland, NJ, U.S.A.). Samples were mixed with $0.5 \mathrm{ml}$ of sterile water, and then, serial dilutions were made and spotted (10 $\mu$ l per spot) in triplicate on GYE agar plates with appropriate antibiotics. Plates were incubated at $28^{\circ} \mathrm{C}$ until single colonies could be counted. The number of $\mathrm{CFU}$ per square centimeter of leaf area was then estimated, and standard deviation was calculated using colony counts from the three triplicate spots from each of three samples per timepoint per inoculum. Experiments were repeated at least three times.

\section{Construction of BLS303hrcC ${ }^{-}$.}

pTOPOhrcC174-781, which is not replicated in Xanthomonas spp., was introduced into X. oryzae pv. oryzicola BLS303. Recombinants were selected on GYE plates containing kanamycin. Disruption of $h r c C$ by single homologous recombination was assayed by PCR, using the M13forward(-20) primer corresponding to the vector sequence upstream of the insert in pTOPOhrcC174-781 and primer SM25 (5'-ATGGCTCCTGC CTGTACCA-3'), which corresponds to the $3^{\prime}$ end of $h r c C$. Each of five isolates showing disruption of $h r c C$ was inoculated to rice and confirmed to be nonpathogenic. One was chosen arbitrarily for coinoculation experiments and was designated as BLS303hrc $C^{-}$.

\section{Immunodetection of AvrXa10.}

$X$. oryzae pv. oryzicola BLS303(pHMavrXa10), alongside $X$. oryzae pv. oryzae $\mathrm{PXO} 99^{\mathrm{A}}$ (pHMavrXa10) and $X$. oryzae pv. oryzicola BLS303 as positive and negative controls, respectively, were grown in $\mathrm{NBY}$ to $\mathrm{OD}_{600}=0.7$. As described above, AvrXa10 encoded by pHMavrXa10 contains the FLAG epitope (Brizzard et al. 1994). For each culture, cells $(2 \mathrm{ml})$ were resuspended in $75 \mu \mathrm{l}$ of $1 \times$ Laemmli buffer (Laemmli 1970), and cultures were heated to $100^{\circ} \mathrm{C}$ for 3 min to obtain total cellular proteins. Polyacrylamide (10\%) gel electrophoresis and Western blotting of samples was performed using a standard protocol (Bowen et al. 1980). Mouse monoclonal anti-FLAG antibody (Sigma, St. Louis) followed by rabbit anti-mouse antibody conjugated to peroxidase (Pierce, Rockford, IL, U.S.A.) and ECL Plus Western blotting detection system (Amersham, Piscataway, NJ, U.S.A.) with Blue sensitive autoradiography film (Midwest Scientific, St. Louis) were used according to manufacturer protocols to detect AvrXa10.

\section{Cya reporter assay.}

Rice leaves were infiltrated with bacterial suspensions at $\mathrm{OD}_{600}=0.5$ by needleless syringe. After inoculation $(8 \mathrm{~h})$, two replicate samples of $5-\mathrm{cm}$ lengths containing four inoculated spots each were collected, frozen in liquid nitrogen, and were ground with a plastic pestle to a powder. The ground leaf tissues were resuspended in $250 \mu \mathrm{l}$ of $0.1 \mathrm{M} \mathrm{HCl}$ and were centrifuged briefly. The supernatants were assayed with the Correlate-EIA cAMP immunoassay kit (Assay Designs, Ann Arbor, MI, U.S.A.) according to the manufacturer's directions, with three technical repeats for each sample. The amount of total proteins in each sample for normalization was determined by the BCA protein assay kit (Pierce).

\section{ACKNOWLEDGMENTS}

We are grateful to K. Vogel for technical support, L. Wang for help with the adenylate cyclase assays, and B. Yang for helpful discussion. This work was supported by a grant (award number 0227357) from the Plant Genome Research Program of the National Science Foundation to A. J. Bogdanove and by a grant (proposal 2000-02698) from the United States Department of Agriculture CSREES/NRI program to F. White.

\section{LITERATURE CITED}

Abramovitch, R. B., and Martin, G. B. 2004. Strategies used by bacterial pathogens to suppress plant defenses. Curr. Opin. Plant Biol. 7:356-364.

Abramovitch, R. B., and Martin, G. B. 2005. AvrPtoB: A bacterial type III effector that both elicits and suppresses programmed cell death associated with plant immunity. FEMS (Fed. Eur. Microbiol. Soc.) Microbiol. Lett. 245:1-8.

Alfano, J. R., and Collmer, A. 2004. Type III secretion system effector proteins: Double agents in bacterial disease and plant defense. Annu. Rev. Phytopathol. 42:385-414.

Bai, J., Choi, S.-H., Ponciano, G., Leung, H., and Leach, J. E. 2000. Xanthomonas oryzae pv. oryzae avirulence genes contribute differently and specifically to pathogen aggressiveness. Mol. Plant-Microbe Interact. 13:1322-1329.

Ballvora, A., Pierre, M., van den Ackerveken, G., Schornack, S., Rossier, O., Ganal, M., Lahaye, T., and Bonas, U. 2001. Genetic mapping and functional analysis of the tomato $B s 4$ locus governing recognition of the Xanthomonas campestris pv. vesicatoria AvrBs4 protein. Mol. PlantMicrobe Interact. 14:629-638.

Bogdanove, A. J., Beer, S. V., Bonas, U., Boucher, C., Collmer, A., Coplin, D. L., Cornelis, G. R., Huang, H.-C., Hutchenson, S. W., Panopoulos, N. J., and Van Gijsegem, F. 1996. Unified nomenclature for broadly conserved hrp genes of phytopathogenic bacteria. Mol. Microbiol. 20:681-683.

Bonas, U., Stall, R. E., and Staskawicz, B. 1989. Genetic and structural characterization of the avirulence gene avrBs3 from Xanthomonas campestris pv. vesicatoria. Mol. Gen. Genet. 218:127-136.

Bowen, B., Steinberg, J., Laemmli, U. K., and Weintraub, H. 1980. The detection of DNA-binding proteins by protein blotting. Nucleic Acids Res. 8:1-20.

Brizzard, B. L., Chubet, R. G., and Vizard, D. L. 1994. Immunoaffinity purification of FLAG epitope-tagged bacterial alkaline phosphatase using a novel monoclonal antibody and peptide elution. BioTechniques 16:730-735.

Brunings, A. M., and Gabriel, D. W. 2003. Xanthomonas citri: Breaking the surface. Mol. Plant Pathol. 4:141-157.

Buttner, D., and Bonas, U. 2002. Getting across-Bacterial type III effector proteins on their way to the plant cell. EMBO (Eur. Mol. Biol. Organ.) J. 21:5313-5322.

Buttner, D., Gurlebeck, D., Noel, L. D., and Bonas, U. 2004. HpaB from Xanthomonas campestris pv. vesicatoria acts as an exit control protein in type III-dependent protein secretion. Mol. Microbiol. 54:755-768.

Casper-Lindley, C., Dahlbeck, D., Clark, E. T., and Staskawicz, B. J. 2002. Direct biochemical evidence for type III secretion-dependent translocation of the AvrBs2 effector protein into plant cells. Proc. Natl. Acad. Sci. U.S.A. 99:8336-8341.

Chang, J. H., Goel, A. K., Grant, S. R., and Dangl, J. L. 2004. Wake of the flood: Ascribing functions to the wave of type III effector proteins of phytopathogenic bacteria. Curr. Opin. Microbiol. 7:11-18.

Choi, S. H., and Leach, J. E. 1994. Genetic manipulation of Xanthomonas oryzae pv. oryzae. Int. Rice Res. Notes 19:31-32.

Cornelis, G. R., and Van Gijsegem, F. 2000. Assembly and function of type III secretory systems. Annu. Rev. Microbiol. 54:735-774.

Das, S. R. 1977. Assessment of rice varieties for resistance to bacterial leaf streak disease caused by Xanthomonas translucens f. sp. oryzicola. Sci. Cult. 43:93.

DebRoy, S., Thilmony, R., Kwack, Y.-B., Nomura, K., and He, S.-Y. 2004. A family of conserved bacterial effectors inhibits salicylic acid-mediated basal immunity and promotes disease necrosis in plants. Proc. Natl. Acad. Sci. U.S.A. 101:9927-9932.

Flor, H. H. 1971. Current status of the gene-for-gene concept. Annu. Rev. Phytopathol. 9:275-296.

Greenberg, J. T., and Yao, N. 2004. The role and regulation of programmed cell death in plant-pathogen interactions. Cell. Microbiol. 6:201-211.

Gu, K., Yang, B., Tian, D., Wu, L., Wang, D., Sreekala, C., Yang, F., Chu, Z., Wang, G.-L., White, F. F., and Yin, Z. 2005. $R$ gene expression induced by a type-III effector triggers disease resistance in rice. Nature 435:1122-1125.

Hammond-Kosack, K. E., and Jones, J. D. G. 1996. Resistance gene-dependent plant defense responses. Plant Cell 8:1773-1791.

Herbers, K., Conrads-Strauch, J., and Bonas, U. 1992. Race-specificity of plant resistance to bacterial spot disease determined by repetitive motifs in a bacterial avirulence protein. Nature 356:172-174.

Hopkins, C. M., White, F. F., Choi, S. H., Guo, A., and Leach, J. E. 1992. Identification of a family of avirulence genes from Xanthomonas oryzae pv. oryzae. Mol. Plant-Microbe Interact. 5:451-459.

Hueck, C. J. 1998. Type III protein secretion systems in bacterial pathogens of animals and plants. Microbiol. Mol. Biol. Rev. 62:379-433. 
Innes, R. W., Hirose, M. A., and Kuempel, P. L. 1988. Induction of nitrogen-fixing nodules on clover requires only 32 kilobase pairs of DNA from the Rhizobium trifolii symbiosis plasmid. J. Bacteriol. 170:37933802.

Keen, N. T. 1990. Gene-for-gene complementarity in plant-pathogen interactions. Annu. Rev. Genet. 24:447-463.

Kim, H.-S., Desveaux, D., Singer, A. U., Patel, P., Sondek, J., and Dangl, J. L. 2005. The Pseudomonas syringae effector AvrRpt 2 cleaves its Cterminally acylated target, RIN4, from Arabidopsis membranes to block RPM1 activation. Proc. Natl. Acad. Sci. U.S.A. 102:6496-6501.

Klement, Z. 1982. Hypersensitivity. Pages 149-177 in: Phytopathogenic Prokaryotes. M. S. Mount and G. S. Lacy, eds. Academic Press, New York.

Laemmli, U. K. 1970. Cleavage of structural proteins during the assembly of the head of bacteriophage T4. Nature 227:680-685.

Lee, K. S., Rasabandith, S., Angeles, E. R., and Khush, G. S. 2003. Inheritance of resistance to bacterial blight in 21 cultivars of rice. Phytopathology 93:147-152.

Martin, G. B., Bogdanove, A. J., and Sessa, G. 2003. Understanding the functions of plant disease resistance proteins. Annu. Rev. Plant Biol. 54:23-61.

Metz, M., Dahlbeck, D., Morales, C. Q., Sady, B. A., Clark, E.T., and Staskawicz, B. J. 2005. The conserved Xanthomonas campestris pv. vesicatoria effector protein XopX is a virulence factor and suppresses host defense in Nicotiana benthamiana. Plant J. 41:801-814.

Mew, T. W. 1993. Xanthomonas oryzae pathovars on rice: Cause of bacterial blight and bacterial leaf streak. Pages 30-40 in: Xanthomonas. J. G. Swings and E. L. Civerolo, eds. Chapman and Hall, New York.

Mew, T. W., Alvarez, A. M., Leach, J. E., and Swings, J. 1993. Focus on bacterial blight of rice. Plant Dis. 77:5-12.

Miao, E. A., Scherer, C. A., Tsolis, R. M., Kingsley, R. A., Adams, L. G., Baumler, A. J., and Miller, S. I. 1999. Salmonella typhimurium leucinerich repeat proteins are targeted to the SPI1 and SPI2 type III secretion systems. Mol. Microbiol. 34:850-864.

Mudgett, M. B., Chesnokova, O., Dahlbeck, D., Clark, E. T., Rossier, O., Bonas, U., and Staskawicz, B. J. 2000. Molecular signals required for type III secretion and translocation of the Xanthomonas campestris AvrBs2 protein to pepper plants. Proc. Natl. Acad. Sci. U.S.A. 97:13324-13329.

Noda, T., Yamamoto, T., Kaku, H., and Horino, O. 1996. Geographical distribution of pathogenic races of Xanthomonas oryzae pv. oryzae in Japan in 1991 and 1993. Ann. Phytopathol. Soc. Japan 62:549-553.

Ou, S. H. 1985. Rice Diseases. Commonwealth Agricultural Bureau, Kew, Surrey.

Rao, Y. P., Shekhawat, G. S., Mohan, S. K., and Reddy, P. R. 1972. Evaluation of rice varieties for resistance to bacterial leaf-streak (Xanthomonas translucens). Ind. J. Agr. Sci. 42:502-505.

Sambrook, J., Fritsch, E. F., and Maniatis, T. E. 1989. Molecular Cloning: A Laboratory Manual. Cold Spring Harbor Laboratory Press, Cold Spring Harbor, NY. U.S.A.

Schaad, N. W., Wang, Z. K., Di, M., McBeath, J., Peterson, G. L., and Bonde, M. R. 1996. An improved infiltration technique to test the pathogenicity of Xanthomonas oryzae pv. oryzae in rice seedlings. Seed Sci. Technol. 24:449-456.

Soby, S. D., and Daniels, M. J. 1996. Catabolite-repressor-like protein regulates the expression of a gene under the control of the Escherichia coli lac promoter in the plant pathogen Xanthomonas campestris pv. campestris. Appl. Microbiol. Biotechnol. 46:559-561.

Sory, M. P., and Cornelis, G. R. 1994. Translocation of a hybrid YopE-adenylate cyclase from Yersinia enterocolitica into HeLa cells. Mol. Microbiol. 14:583-594.

Swarup, S., De Feyter, R., Brlansky, R. H., and Gabriel, D. N. 1991. A pathogenicity locus from Xanthomonas citri enables strains from several pathovars of Xanthomonas campestris to elicit canker-like lesions on citrus. Phytopathology 81:802-808

Swings, J., Van Den Mooter, M., Vauterin, L., Hoste, B., Gillis, M., Mew, T. W., and Kersters, K. 1990. Reclassification of the causal agents of bacterial blight (Xanthomonas campestris pathovar oryzae) and bacterial leaf streak (Xanthomonas campestris pathovar oryzicola) of rice as pathovars of Xanthomonas oryzae new species (ex Ishiyama 1922) sp. nov., nom. rev. Int. J. Syst. Bacteriol. 40:309-311.

Szurek, B., Marois, E., Bonas, U., and van den Ackerveken, G. 2001. Eukaryotic features of the Xanthomonas type III effector AvrBs3: Protein domains involved in transcriptional activation and the interaction with nuclear import receptors from pepper. Plant J. 26:523-534.

Szurek, B., Rossier, O., Hause, G., and Bonas, U. 2002. Type III-dependent translocation of the Xanthomonas AvrBs3 protein into the plant cell. Mol. Microbiol. 46:13-23.

Tang, D., Wu, W., Li, W., Lu, H., and Worland, A. J. 2000. Mapping of QTLs conferring resistance to bacterial leaf streak in rice. Theor. Appl. Genet. 101:286-291.

Tsuge, S., Furutani, A., Fukunaka, R., Kubo, Y., and Horino, O. 2001. Growth complementation of hrpXo mutants of Xanthomonas oryzae pv. oryzae by virulent strains in rice cultivars resistant and susceptible to the parental strain. J. Gen. Plant Pathol. 67:51-57.

Van Der Bij, A. J., De Weger, L. A., Tucker, W. T., and Lugtenberg, B. J. J. 1996. Plasmid stability in Pseudomonas fluorescens in the rhizosphere. Appl. Environ. Microbiol. 62:1076-1080.

Vidaver, A. K. 1967. Synthetic and complex media for the rapid detection of fluorescence of phytopathogenic pseudomonads: Effect of the carbon source. Appl. Microbiol. 15:1523-1524.

Wright, C. A., and Beattie, G. A. 2004. Pseudomonas syringae pv. tomato cells encounter inhibitory levels of water stress during the hypersensitive response of Arabidopsis thaliana. Proc. Natl. Acad. Sci. U.S.A. 101:3269-3274.

Yang, B., and White, F. F. 2004. Diverse members of the AvrBs3/PthA family of type III effectors are major virulence determinants in bacterial blight disease of rice. Mol. Plant-Microbe Interact. 17:1192-1200.

Yang, B., Zhu, W., Johnson, L. B., and White, F. F. 2000. The virulence factor AvrXa7 of Xanthomonas oryzae pv. oryzae is a type III secretion pathway-dependent nuclear-localized double-stranded DNA-binding protein. Proc. Natl. Acad. Sci. U.S.A. 97:9807-9812.

Yang, B., Sugio, A., and White, F. F. 2005. Avoidance of host recognition by alterations in the repetitive and C-terminal regions of AvrXa7, a type III effector of Xanthomonas oryzae pv. oryzae. Mol. Plant-Microbe Interact. 18:142-149.

Yang, Z., Sun, X., Wang, S., and Zhang, Q. 2003. Genetic and physical mapping of a new gene for bacterial blight resistance in rice. Theor Appl. Genet. 106:1467-1472.

Zhao, B., Ardales, E. Y., Raymundo, A., Bai, J., Trick, H. N., Leach, J. E., and Hulbert, S. H. 2004. The avrRxol gene from the rice pathogen Xanthamonas oryzae pv. oryzicola confers a nonhost defense reaction on maize with resistance gene Rxo1. Mol. Plant-Microbe Interact. 17:771 779.

Zhao, B., Lin, X., Poland, J., Trick, H., Leach, J., and Hulbert, S. 2005. A maize resistance gene functions against bacterial streak disease in rice. Proc. Natl. Acad. Sci. U.S.A. 102:15383-15388.

Zhu, W., Yang, B., Chittoor, J. M., Johnson, L. B., and White, F. F. 1998 AvrXa10 contains an acidic transcriptional activation domain in the functionally conserved C-terminus. Mol. Plant-Microbe Interact. 11:824-832.

Zhu, W., Yang, B., Wills, N., Johnson, L. B., White, F. F., Zhu, W. G., and Yang, B. 1999. The C-terminus of AvrXa10 can be replaced by the transcriptional activation domain of VP16 from the herpes simplex virus. Plant Cell 11:1665-1674

Zhu, W., MaGbanua, M. M., and White, F. F. 2000. Identification of two novel hrp-associated genes in the hrp gene cluster of Xanthomonas oryzae pv. oryzae. J. Bacteriol. 182:1844-1853. 